\title{
$\mathrm{Fe}$-低 Al 合金の $1073 \mathrm{~K}$ における 内部酸化挙動に及ぼす $\mathrm{Al}$ 濃度の影響
}

\author{
林重成 ${ }^{\dagger}$ 成田敏夫
}

北海道大学大学院工学研究科界面制御工学講座

J. Japan Inst. Metals, Vol. 63, No. 9 (1999), pp. 1204-1211

\section{Effect of Al Content on the Internal Oxidation of Fe-Low Al Alloys at $1073 \mathrm{~K}$}

\section{Shigenari Hayashi ${ }^{\dagger}$ and Toshio Narita}

\begin{abstract}
Research Group of Interface Control Engineering, Graduate School of Engineering, Hokkaido University, Sapporo 060-8628
\end{abstract}

\begin{abstract}
Oxidation properties of $\mathrm{Fe}-3,5$ and 7 mass $\% \mathrm{Al}$ alloys were investigated at $1073 \mathrm{~K}$ in an oxygen gas atmosphere for up to $14.4 \mathrm{ks}$ using thermo-gravimetry, scanning electron microscope, electron probe microanalyzer, and X-ray diffraction analysis. Time dependence of oxidation amounts can be divided into three regions, i.e., an initial stage with very high oxidation rate, a transient stage with a rapid decrease in the rate, and then a steady state oxidation. The critical times among these stages are 0.1 and $3.6 \mathrm{ks}$. The $7 \mathrm{Al}$ alloy oxidized very slowly, due to the formation of a duplex $\mathrm{Al}_{2} \mathrm{O}_{3}$ and $\mathrm{Fe}_{2} \mathrm{O}_{3}$ scale, in contrast to rapid oxidation of both $5 \mathrm{Al}$ and $3 \mathrm{Al}$ alloys. The $5 \mathrm{Al}$ alloy oxidized faster than the $3 \mathrm{Al}$ alloy during the initial stage, while for longer oxidation the $3 \mathrm{Al}$ alloy became faster. The $3 \mathrm{Al}$ alloy oxidized to form a thick scale with a triplex structure of $\mathrm{Fe}_{2} \mathrm{O}_{3}, \mathrm{Fe}_{3} \mathrm{O}_{4}$ and $\mathrm{FeAl}_{2} \mathrm{O}_{4}$, accompanied with an internal oxidation of duplex $\mathrm{FeAl}_{2} \mathrm{O}_{4}$ and $\mathrm{Al}_{2} \mathrm{O}_{3}$ zones. These internal oxides grew perpendicular to the alloy/scale interface. Oxidation of the $5 \mathrm{Al}$ alloy, close to the internal-external transition composition, is very complex depending on portions and oxidation times. It has a thin scale like the $7 \mathrm{Al}$ alloy and a thick scale with internal oxides like the $3 \mathrm{Al}$ alloy. Further, a precipitate free zone (PFZ) formed in the internal oxidation, sandwiched in between the $\mathrm{FeAl}_{2} \mathrm{O}_{4}$ and $\mathrm{Al}_{2} \mathrm{O}_{3}$ zones, and the formation mechanism of $\mathrm{PFZ}$ was proposed.

(Received April 22, 1999; In Final Form June 28, 1999)
\end{abstract}

Keywords: iron-aluminum alloy, oxidation rate, morphology of internal oxides, aluminum contents, precipitates free zone, transition from internal to external oxidation, internal oxidation zone

\section{I . 緒 言}

$\mathrm{Fe}-\mathrm{Al}$ 合金の高温酸化挙動は $\mathrm{Al}$ 濃度に依存して変化する。

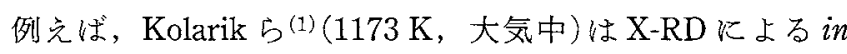
situ観察から，表面スケールは5\% $\mathrm{Al}$ 合金では $\mathrm{Fe}_{2} \mathrm{O}_{3}$, $10 \% \mathrm{Al}$ では $\alpha-\mathrm{Al}_{2} \mathrm{O}_{3}$ と $\mathrm{Fe}_{2} \mathrm{O}_{3}$ の両方が, $20 \% \mathrm{Al}$ 以上では保 護的な $\alpha-\mathrm{Al}_{2} \mathrm{O}_{3}$ スケールが観察されることを示した。 Ahmed $ら^{(2)}$ は， Fe-1.5 5 at\% $\mathrm{Al}$ 合金の $1173 \mathrm{~K}$ ，純酸素中 飞括ける酸化挙動を詳細比調查し，1.5と 3 at\% $\mathrm{Al}$ では内部 酸化が観察され，内部酸化物は棒状玉たは板状の $\mathrm{FeAl}_{2} \mathrm{O}_{4}$ でその先端に $\mathrm{Al}_{2} \mathrm{O}_{3}$ が生成し，いずれも合金表面に垂直に 成長する事を示した．Al湢度がさらに増加すると，内部酸 化層先端の $\mathrm{Al}_{2} \mathrm{O}_{3}$ はフィルム状に変化し，このフィルム状 $\mathrm{Al}_{2} \mathrm{O}_{3}$ 蛙長時間の酸化で外部酸化スケールになると報告して いる.同样の内部酸化組織性 $\mathrm{Ni}$-低 $\mathrm{Al}$ 合金(3)-(8)でも観察さ れている。

†北海道大学大学院生 (Graduate Student, Hokkaido University)
一方, Tomaszewicz ら ${ }^{(9)}$ は $1073 \mathrm{~K}$, 純酸素中での酸化 実験から， $\mathrm{Al}$ 濃度が 1.9 と $2.4 \% \mathrm{Al}$ の間で内部酸化から外部 酸化に変化し，6.9から 7.3\% Al でノジュールの発生が見ら れなくなり，それ以上の $\mathrm{Al}$ 濃度で恃維密な $\mathrm{Al}_{2} \mathrm{O}_{3}$ 皮膜へ遷 移することを報告している．Fe-Al 合金のノシュール状酸化 物の形成は, Smith ら (10)やSaegusaら(11)がそれぞれ Fe-6 at \% Al, Fe-5 mass\% $\%$ Al 合金の $1173 \mathrm{~K}$ ，純酸素中の酸化実験 で，また Boggs ${ }^{(12)}$ が $1073 \mathrm{~K}$, 純酸素扰上び酸素-水蒸気混 合ガス中の酸化実験で報告している.

$\alpha-\mathrm{Al}_{2} \mathrm{O}_{3}$ が安定に生成すると言われている $1173 \mathrm{~K}$ 以上の 温度域での Fe-Al 合金の酸化挙動については, Ahmed らの 報告に見られるよらに，詳細な研究が行われているのに対し て，Fe-Al 合金および A 1 払散処理鋼が実用環境で遭遇する 機会が多いと予想さ礼る $1173 \mathrm{~K}$ 以下での酸化挙動について は不明な点が残されている. Tomaszewiczらの研究に和い て子, 内部酸化から外部酸化への遷移機構については汪とん

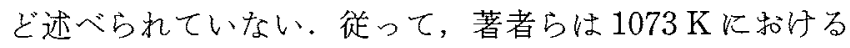
$\mathrm{Fe}-\mathrm{Al}$ 合金の高温腐食(純酸素, 空気, 乱よびそれらへの水 蒸気添加) 挙動を解明するための一連の研究(13)(14)を進めて 
Wる.

本研究では， $1073 \mathrm{~K}$ ，純酸素ガス雾囲気，比較的短時間 に打ける Fe-低 $\mathrm{Al}$ 合金の酸化挙動を調查し，特に，内部酸 化から外部酸化への遷移と内部酸化形態に及ぼす $\mathrm{Al}$ 濃度と 酸化時間の影響について検討した。

\section{II. 実 験 方 法}

$\mathrm{Fe}-3,5,7$ mass \% Al 合金(ここでは，3A1, 5A1, 7Al と呼ぶ) は，電解鉄 $(99.98$ mass\%) と電解アルミニウム $(99.998$ mass\%)を出発原料として, Ar アーク溶解炉で溶製(約 $40 \mathrm{~g}$ インゴット)し，次いで，Ar ガス䨌囲気， $1473 \mathrm{~K}, 86.4 \mathrm{ks}$ の条件下で均質化熱処理を行った。

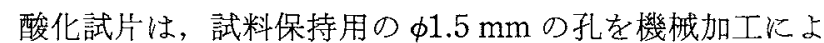
り開けた後，耐水研磨紙１500まで，続いて表裹面を $3 \mu \mathrm{m}$ のダイアモンドペーストで鏡面研磨し，メタノール・ベンゼ ン $(1: 1)$ 混合溶液で超音波洗浄を行って酸化実験に供した. 試料の表面積は約 $2 \mathrm{~cm}^{2}$ ，厚さ $200 \mu \mathrm{m}$ である.

酸化以純酸素(公称純度 : $99.9 \%$ ) 雾团気, 温度 $1073 \mathrm{~K}$,

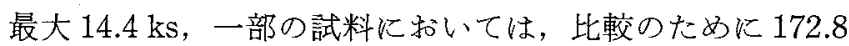
ks 委で行った。酸化実験装置の概略をFig. 1 亿示す。試料 を $\mathrm{Pt}$ 線で石英フックに取り付け，反応管内を高純度 $\mathrm{Ar}$ ガ ス $(6 \mathrm{~N}$ 純度) で数回ガス置換した後，Ar ガスを流しながら， 先ず，電気炉を $0.17 \mathrm{~K} / \mathrm{s}$ で昇温した．実験温度に到達後， 試料が反応管の均熱部にくるように電気炉を降下させ，試料 直近に和いた熱電対の温度が実験温度に達した時点で純酸素 ガスに切り替えた。酸化実験中の反応管内の酸素がス線速は $6.5 \times 10^{-3} \mathrm{~m} / \mathrm{s}$ であ。酸化重量は自記式熱天秤(舄津製作 所 TGA-40)を用いて連続測定した。所定時間経過後，酸素 ガスから Ar ガスに変更し，ただらに電気炉を持ち上げ，試 料は Ar ガス流中で泠却した。

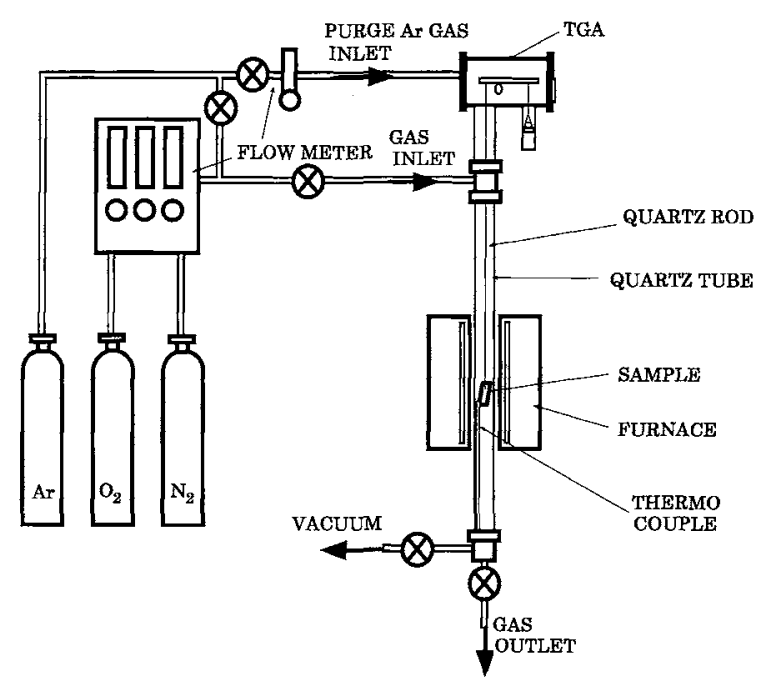

Fig. 1 Schematic representation of an oxidation apparatus used.
酸化試料の表面スケールと断面組織の観察および元素分析 はSEM とEPMAでまた腐食生成物の同定はX-RDを用 いて行った。 EPMAの加速電圧は $15 \mathrm{kV}$, 吸収電流は $3 \times$ $10^{-8} \mathrm{~A}, \mathrm{X}-\mathrm{RD}$ は $\mathrm{Cu}$ ターゲット, $30 \mathrm{kV}, 300 \mathrm{~mA}, \mathrm{Ni} フ$ ィ ルターを使用した。

\section{III. 結 果}

\section{1. 酸化の動力学}

Fig. 2 は $3 \mathrm{~A} 1,5 \mathrm{Al}, 7 \mathrm{Al}$ 合金を，酸素雾囲気中，1073 K で酸化した際の質量変化の時間依存性を示す。これより，い ずれの合金でも，酸化の時間低存性は酸化量が急速に増加す る初期段階とそれに続く比較的ゆっくりした酸化を示吉後期 段階に大別される。14.4 ks 酸化後の腐食量は $3 \mathrm{Al}, 5 \mathrm{Al}$ と

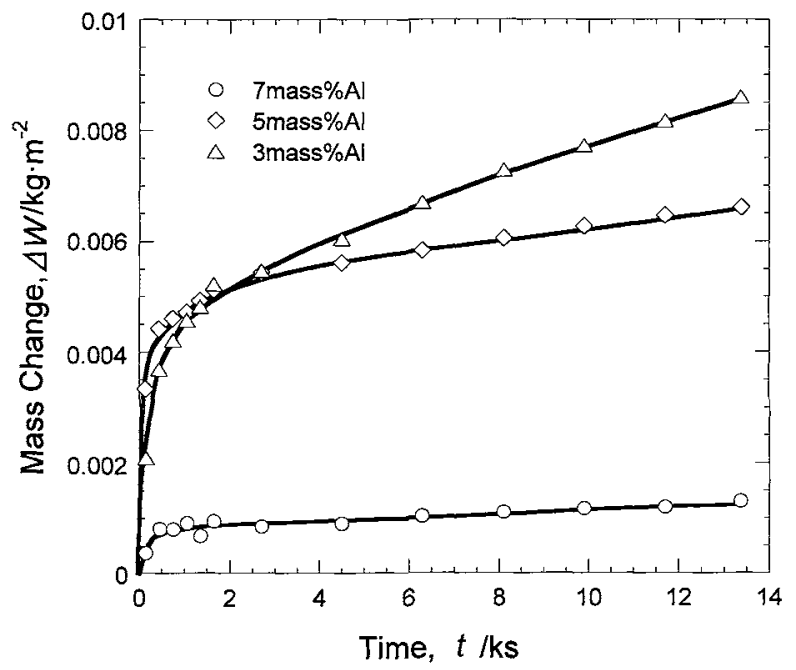

Fig. 2 Change in mass gain with time for $\mathrm{Fe}-3,5$ and 7 mass\% $\mathrm{Al}$ alloys, during the oxidation at $1073 \mathrm{~K}$ in an $\mathrm{O}_{2}$ atmosphere.

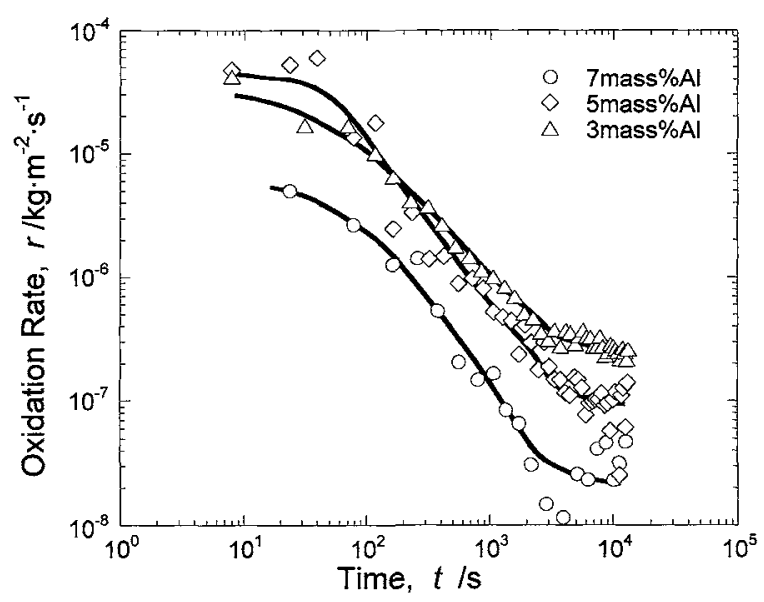

Fig. 3 Change in oxidation rates with time for $\mathrm{Fe}-3,5$ and 7 mass $\% \mathrm{Al}$ alloys, during the oxidation at $1073 \mathrm{~K}$ in an $\mathrm{O}_{2}$ atmosphere. 
$7 \mathrm{Al}$ の順に低下するが，3Al と5Al は酸化の初期に大きな腐 食量を示した後徐々に増加しているのに対して，7A1 合金は 初期酸化量が少なく，その後の酸化もゆっくりと進行してい ることがわかる。

Fig. 3 はFig. 2 飞示した酸化量の時間変化から酸化速度 を求め，酸化時間に対してプロットしたものである。これよ り，酸化のごく初期(100 s 以内)では， $5 \mathrm{Al}$ が $3 \mathrm{Al}$ よりも若 干大きな速度を示し，時間の経過とともに，3Al よりも早く 低下する傾向を有する。一方，7A1 は酸化の初期加ら約 1 桁 小さい速度となっている。いずれの合金も，100 s から数 $\mathrm{ks}$ の間では，酸化速度は時間に対して両対数プロットなるとき 直線的に減少し，さらに長時間になると，上りゆっくりと低 下する．酸化後期段階の酸化速度心 $3 \mathrm{Al}, 5 \mathrm{Al}, 7 \mathrm{Al}$ の順に低 い.こ扎ら酸化速度の時間変化から，初期から後期への遷移 時間は約 $3 \mathrm{ks}$ と見積もられる。

\section{2. 断面構造}

Fig. 4(a)は，7Al 合金を $1073 \mathrm{~K}, 14.4 \mathrm{ks}$ 酸化した試料の 断面組織，またFig. 5(a)は，EPMAによる各元素の定量 分析の結果を示す。酸化皮膜の厚さが約 $1 \mu \mathrm{m}$ と薄いため
EPMA の分析精度は劣るが，外層は $\mathrm{Fe}_{2} \mathrm{O}_{3}$ ，内層は $\mathrm{Al}_{2} \mathrm{O}_{3}$ であると推定される。しかし，合金内部には酸化物の形成は 認められない。

Fig. 4(b) は $3 \mathrm{Al}$ を $14.4 \mathrm{ks}$ 酸化した試料の断面組織であ り，そのEPMA 分析結果をFig. 5(b)に示す。表面スケ一 ルはガス側に $\mathrm{Fe}_{2} \mathrm{O}_{3}$ と内側に $\mathrm{FeAl}_{2} \mathrm{O}_{4}$ の 2 層構造を有する. さらに，合金内部には複層の内部酸化物が観察され，表面側 の酸化物は $\mathrm{FeAl}_{2} \mathrm{O}_{4}$, 合金内部では $\mathrm{Al}_{2} \mathrm{O}_{3}$ であり，いずれも スケール/合金界面に対して垂直方向に伸びた䋐維状の形態 をとっている。析出物の大きさは合金内側の方がより大き く，悉た， $\mathrm{FeAl}_{2} \mathrm{O}_{4}$ は合金内部に行くにつ机てより粗になっ ている．合金内部加ら内部酸化物層先端に向かって脱 $\mathrm{A} 1$ 層 が形成し，また，複層内部酸化物の間に，酸化物が少ない層 が存在していることがわかる.

比較のために，3A1 $172.8 \mathrm{ks}$ 酸化させた試料の断面組 織とEPMA による各元素の線分析結果をそれぞれFig. 4(c)，(d) 和よびFig. 6 に示与。これより，内部酸化層の組 織に注目すると，合金側の層 $\left(\mathrm{Al}_{2} \mathrm{O}_{3}\right)$ がより厚く成長してい ることがわかる。さらに，Fig. 4(d)飞示すよらに，内部酸 化層先端にフィルム状の $\mathrm{Al}_{2} \mathrm{O}_{3}$ 酸化物が生成している部分

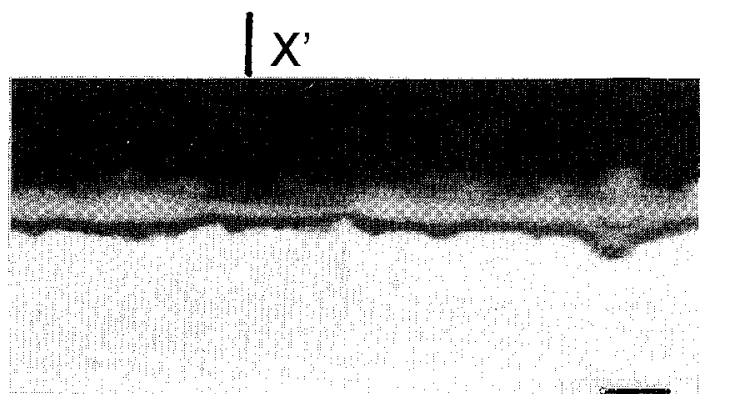

(a)

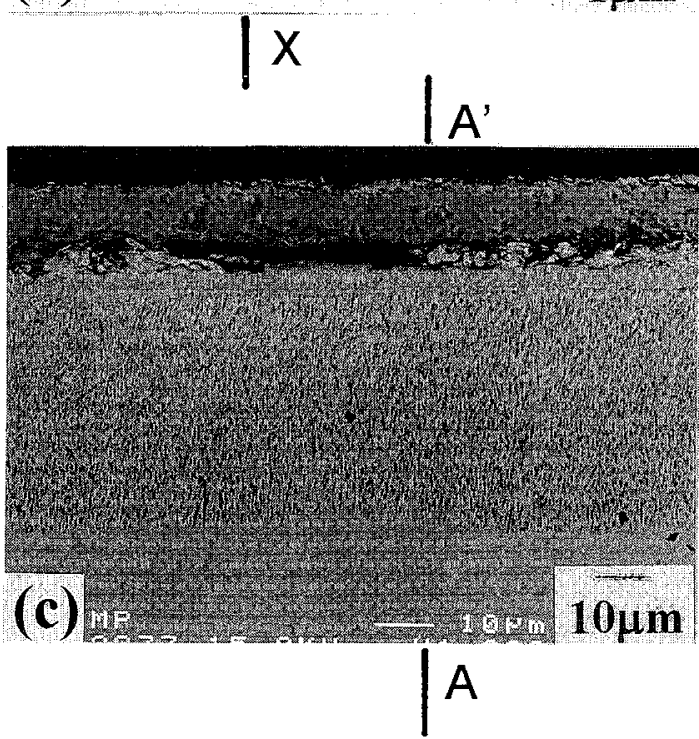

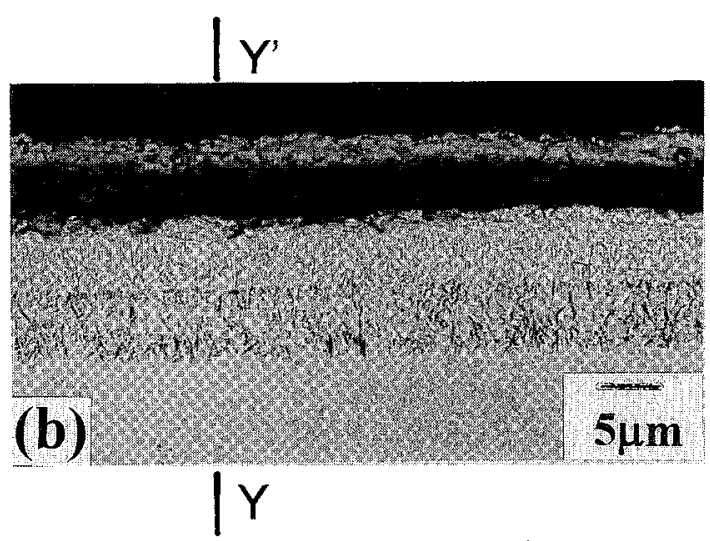

$B^{\prime}$

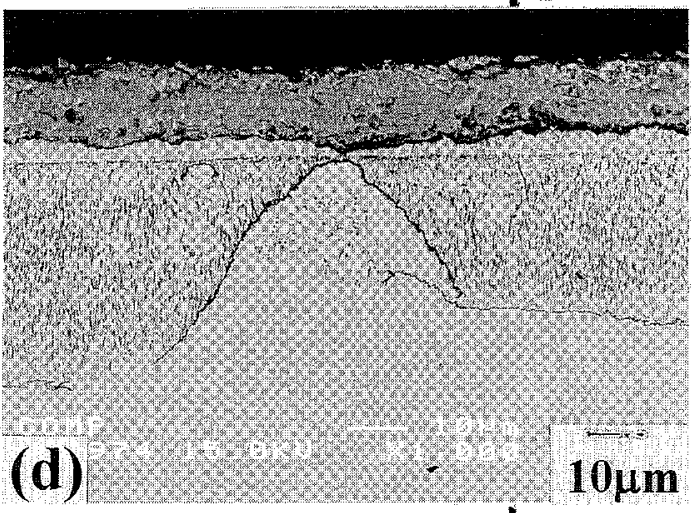

B

Fig. 4 Cross-sectional microstructures of $\mathrm{Fe}-$ low $\mathrm{Al}$ alloys oxidized at $1073 \mathrm{~K}$ in an $\mathrm{O}_{2}$ atmosphere. (a) Fe-7Al alloy for $14.4 \mathrm{ks}$, (b) Fe-3Al alloy for $14.4 \mathrm{ks}$, and (c), (d) $\mathrm{Fe}-3 \mathrm{Al}$ alloy for $172.8 \mathrm{ks}$. 

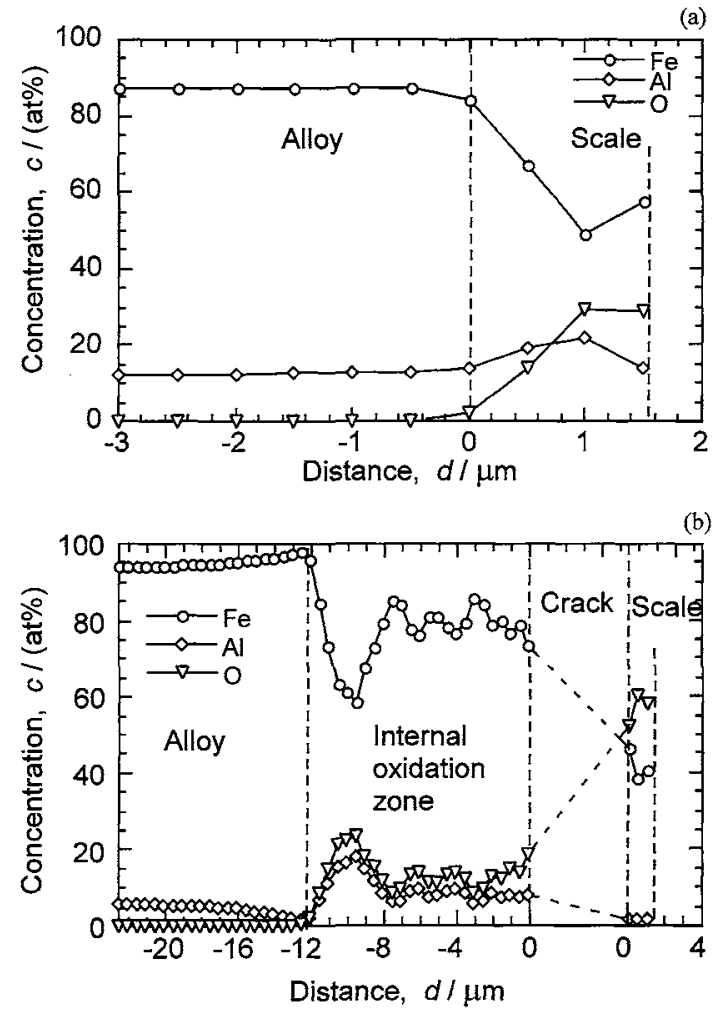

Fig. 5 Concentration profiles of $\mathrm{Fe}, \mathrm{Al}$ and $\mathrm{O}$ measured by EPMA along lines $\mathrm{X}-\mathrm{X}^{\prime}$ and $\mathrm{Y}-\mathrm{Y}^{\prime}$ in Figs. $4(\mathrm{a})$ and $4(\mathrm{~b})$ respectively.
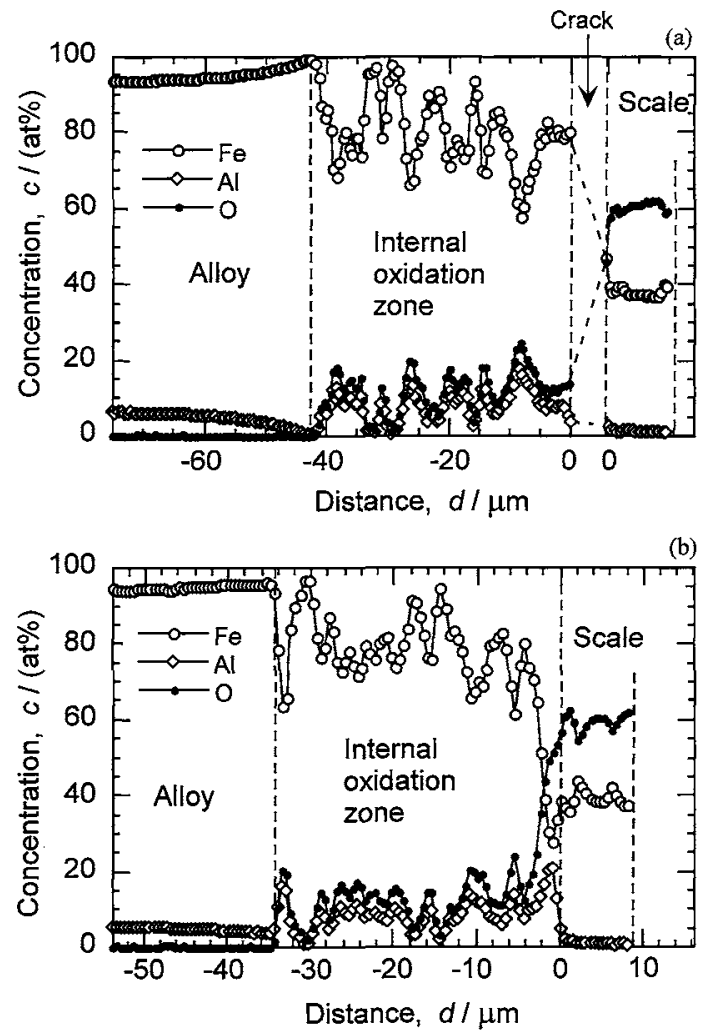

Fig. 6 Concentration profiles of $\mathrm{Fe}, \mathrm{Al}$ and $\mathrm{O}$ measured by EPMA along lines $\mathrm{A}^{-\mathrm{A}^{\prime}}$ and $\mathrm{B}-\mathrm{B}^{\prime}$ in Figs. $4(\mathrm{c})$ and $4(\mathrm{~d})$ respectively.
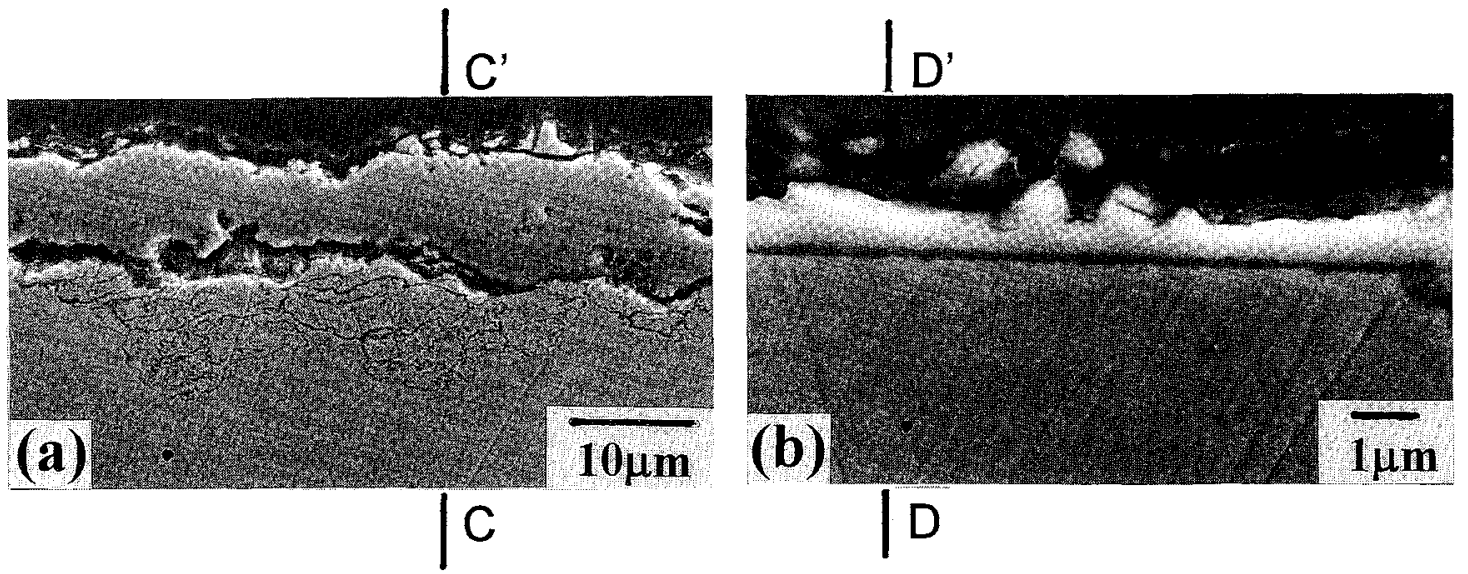

Fig. 7 Cross-sectional microstructures of $\mathrm{Fe}-5 \mathrm{Al}$ alloys oxidized at $1073 \mathrm{~K}$ for $14.4 \mathrm{ks}$ in an $\mathrm{O}_{2}$ atmosphere.

Part (a) is for a thick iron oxides scale with internal oxidation, and part (b) for a thin surface scale without internal oxidation.

が認められる。その部分では内部酸化の成長は抑制されて拉 り，一部は表面スケールに慗がっている。また，EPMA分 析の結果から，フィルム状の酸化物が生成している部分では 母材のAl 濃度の低下はほとえど認められないのに対して, それらが存在しない部分では脱 $\mathrm{Al}$ が生し， $\mathrm{A} 1$ 濃度は汪㾏 0 となっていることがわかる(Fig. 6(a)，(b)参照).

$5 \mathrm{Al}$ 合金を $1073 \mathrm{~K}, 14.4 \mathrm{ks}$ 酸化寸ると, Fig. 7 (a) と (b)
に示すよらに，表面スケールの厚さは不均一であり，薄い酸 化物スケール(Fig. 7 (b)) は $\mathrm{Fe}_{2} \mathrm{O}_{3}$ と $\mathrm{Al}_{2} \mathrm{O}_{3}$ の複層構造を有 し, Fig. 8(b)に示すように合金内部には濃度変化は見られ ない。この結果は，Fig. 4(a)に示した7Alのそれに類似し ている。一方，比較的厚い表面スケールが形成した部分では 内部酸化層も同時に見られる。この部分（Fig.7(a)）での表 面スケールは $\mathrm{Fe}_{2} \mathrm{O}_{3}$ と $\mathrm{Fe}_{3} \mathrm{O}_{4}$ の複層とその下に $\mathrm{FeAl}_{2} \mathrm{O}_{4}$, 
さらに合金内部には $\mathrm{Al}_{2} \mathrm{O}_{3}$ を主体とする酸化物がネットワ 一ク状㳊成している. Fig. 8(a)上り内部酸化層が存在す る合金部分では，Al濃度の低下が見られる。

$5 \mathrm{Al}$ 合金を短時間 $(0.36 \mathrm{ks})$ 酸化した試料では，Fig. 9(a) に示すように, 約 $2 \mu \mathrm{m}$ 程度の厚さの鉄酸化物皮膜と $5 \mu \mathrm{m}$ 程度の内部酸化層が生成していることがわかる。この内部酸 化物の主体は $\mathrm{FeAl}_{2} \mathrm{O}_{4}$ であり，表面に垂直に配向した繊維 状の形態を有し，合金表面側では細かく密に，合金内部に行
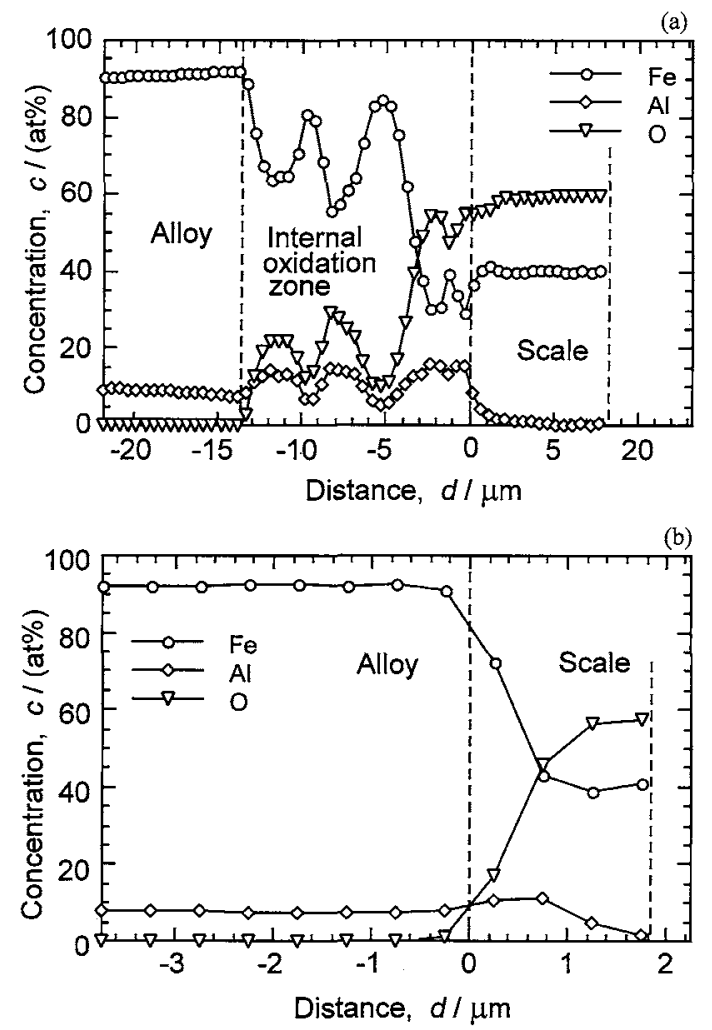

Fig. 8 Concentration profiles of $\mathrm{Fe}, \mathrm{Al}$ and $\mathrm{O}$ measured by EPMA along lines $\mathrm{C}-\mathrm{C}^{\prime}$ and $\mathrm{D}-\mathrm{D}^{\prime}$ in Fig. 7(a) and $7(\mathrm{~b})$ respectively.
くにつれ，長く伸びた粗な形態となっている。寺た，その先 端には塊状の $\mathrm{Al}_{2} \mathrm{O}_{3}$ が薄く形成されている。酸化時間が 3.6 ks 飞なると，Fig. 9(b) 亿示すように，内部酸化層は，表面 側から，粒状酸化物，纎維状酸化物，粒状 + 口ッド状酸化物 を含さ 3 層からなることがわかる，最内層と緎維状酸化物 層の間には酸化物の少ない層が存在する。これら内部酸化層 の構造は3Al(Fig. 5) 镜察されたそれに類似している.

\section{N，考察}

3, 5, 7 mass\% $\mathrm{Al}$ を含む $\mathrm{Fe}-\mathrm{Al}$ 合金を純酸素中，1073 K で酸化した結果, $7 \mathrm{Al}$ 合金では, 酸化速度 $\left(\mathrm{kg} / \mathrm{m}^{2} / \mathrm{s}\right)$ は酸化

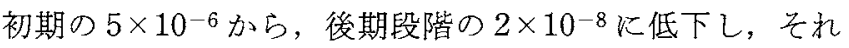
以降惊常以ゆっくりと低下寸る。これは, 断面組織観察と EPMA 分析の結果から，初期段階では $\mathrm{Fe} と \mathrm{Al}$ が同時に酸 化されるが，数 $\mathrm{ks} て ゙ \mathrm{Al}_{2} \mathrm{O}_{3}$ を主体とする内層が緻密に形成 され，保護性を発揮することによる，一方，3A1 では酸化速 度は $4 \times 10^{-5}$ から，数 $\mathrm{ks}$ で括よそ $4 \times 10^{-7}$ に低下した後， 徐々飞低下した。これ性, 酸化初期から表面スケール $\left(\mathrm{Fe}_{2} \mathrm{O}_{3}\right)$ と同時に $\mathrm{FeAl}_{2} \mathrm{O}_{4}$ を主体とする内部酸化層が成長 乙, 時間の経過とともに内部酸化層は $\mathrm{FeAl}_{2} \mathrm{O}_{4}$ の先端に $\mathrm{Al}_{2} \mathrm{O}_{3}$ を主とする酸化層が形成するため, 後期段階では酸化 速度は徐々飞低下寸るものと考光られる。

$5 \mathrm{Al}$ 合金の酸化物は不均質であり，から複雃な時間変化を 示す。すなわち，薄い表面スケールのみを形成している箇所 は7Alのそ礼と類似の機構によって説明される。一方，内 部酸化を伴った厚い垡面スヶールが形成している場所も観察 され，このような部分の内部酸化は, 酸化の初期飞は $\mathrm{FeAl}_{2} \mathrm{O}_{4}$ が主体で, 時間の経過とともに，それより内部に $\mathrm{Al}_{2} \mathrm{O}_{3}$ からなる内部酸化層が成長した。このような内部酸化 層の複層構造は $3 \mathrm{Al}$ のそ机之類似の機構炕よって説明され る.しかし，Fig. 3 に示したよらに，酸化の初期では，5Al は $3 \mathrm{Al}$ よりも大きい酸化速度を有する。これは, 後述する ように，内部酸化層の成長は酸化物と母材との界面を通る酸
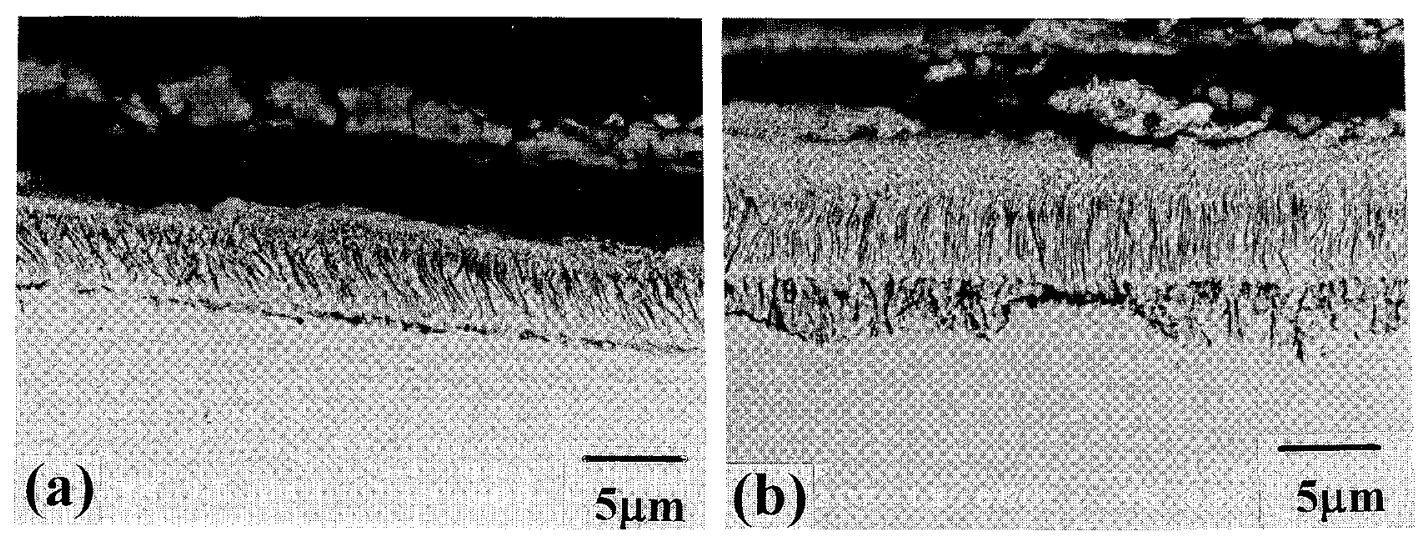

Fig. 9 Cross-sectional microstructures of an $\mathrm{Fe}-5 \mathrm{Al}$ alloy oxidized at $1073 \mathrm{~K}$ in an $\mathrm{O}_{2}$ atmosphere for $300 \mathrm{~s}$ (a) and for $3.6 \mathrm{ks}$ (b). 
素の拡散に支配されていることから，5Al に形成された $\mathrm{FeAl}_{2} \mathrm{O}_{4}$ の数密度が $3 \mathrm{Al}$ のれよりも多いために, 酸化速 度が大さくなったものと理解される.酸化がさらに進行して 後期段階になると，5Al では口ッドまたは粒状の $\mathrm{Al}_{2} \mathrm{O}_{3}$ がネ ットワーク状に変化するため，3Al よりむ酸化速度は低下す ることになる。

本実験の酸化条件下では, 内部酸化加ら外部酸化飞遷移す るときの $\mathrm{Al}$ 濃度は 5 mass\%である。

内部酸化から外部酸化への遷移(15) は, 式(1)で与克られ る。

$$
N_{\mathrm{A} I}^{(\mathrm{O})}>\left[\frac{\pi g^{*}}{2 v} N_{\mathrm{O}}^{(\mathrm{S})} \frac{D_{\mathrm{O}} V_{\text {metal }}}{D_{\mathrm{A} 1} V_{\text {oxide }}}\right]^{1 / 2}
$$

ここで $N_{\mathrm{Al}}^{(0)}, N_{\delta}^{(\mathrm{S})}$ は合金の $\mathrm{Al}$ 濃度和よびスケール/合金 界面の金属中の酸素湮度であり， $D_{0}, D_{\mathrm{Al}}$ はそれぞれ酸素， アルミの鉄中の拡散係数，また， $V_{\text {metal }}, V_{\text {oxide }}$ はそれぞれ合 金とアルミナ $\left(\mathrm{AlO}_{1.5}\right)$ のモル容積である。vは, 化学量論数 でありここでは1.5である。式(1)は，内部酸化層に打ける 合金素地々酸化物の容積割合が臨界値 $g^{*}$ に達すると, 内部 酸化から外部酸化への遷移が起こることを意味する. 現在, $\mathrm{Fe}-\mathrm{Al}$ 合金の酸化に対する $g^{*}$ の值は明らかでないため, 本 実験条件下での Al の遷移濃度を式 (1)を使用して求めるこ とは出来ない，従って，使用した 3 種類の合金の Al 濃度を 用いて $g^{*}$ 值を計算し実験結果との比較を行った。な括，計

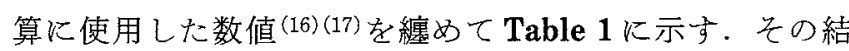
果， $g^{*}$ の值は，7A1，5A1，3A1に対してそれぞれ0.32，0.16， 0.05 となった。 これら $g^{*}$ 值について，例えば， $\operatorname{Rapp}^{(18)}$ は， $\mathrm{Ag}-\mathrm{In}$ 合金の酸化では $g^{*}=0.3$ のさに内部酸化から外部酸 化への遷移が起こることを示した.この Rapp の值を採用す ると、 $3 \mathrm{Al}$ と $7 \mathrm{Al}$ はそれぞれ内部酸化と外部酸化になり, $5 \mathrm{Al}$ はその中間にあることが推定され，実験結果とほぼー一致 する。

纎維状酸化物を含を内部酸化層の形態は, Ahmed ら ${ }^{(2)}$ に

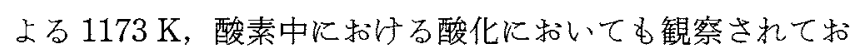
ク，彼らはFig. 10 に示すモデルを提案している.このモデ ルによると, 表面スケールは $\mathrm{Fe}_{2} \mathrm{O}_{3}$ と $(\mathrm{Fe}, \mathrm{Al})_{3} \mathrm{O}_{4}$ であり, $こ の(\mathrm{Fe}, \mathrm{Al})_{3} \mathrm{O}_{4}$ の分解により供給された酸素 $(\mathrm{O})$ が内部酸 化物之合金素地の界面を拡散し, $\mathrm{FeAl}_{2} \mathrm{O}_{4}$ の先端で $\mathrm{Al}_{2} \mathrm{O}_{3}$ を 生成する。な蛒 Fig. 10 中に示した $(\mathrm{Fe}, \mathrm{Al})_{3} \mathrm{O}_{4}$ が直接 $(\mathrm{Fe}$, Al) とO $\mathrm{O}$ 分解する反応は，より低級酸化物を経由すると思 われるが原文のま記載した。一方, 本実験で $3 \mathrm{~A} 1$ に観察 された内部酸化物層は $\mathrm{FeAl}_{2} \mathrm{O}_{4}$ と $\mathrm{Al}_{2} \mathrm{O}_{3}$ 層間に酸化物の少
ない層が存在し, 長時間酸化では内側の $\mathrm{Al}_{2} \mathrm{O}_{3}$ 層が成長し ている等, Ahmedらの提案したモデルでは説明することが できない。

$3 \mathrm{Al}$ 合金に観察された内部酸化物の形成機構を模式的に

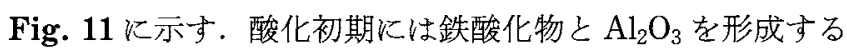
が，拡散速度の大きい鉄酸化物が表面スケールを構成するよ らになり合金表面の酸素分圧が低下し，式(1)から推定さ れたように，3A1 では内部酸化物が形成されることになる (Fig. 11(a)，(b))。このとき，Fig. 12 に示すFe-Al-O 系状 態図 ${ }^{(19)}$ から予測されるように, $\mathrm{FeAl}_{2} \mathrm{O}_{4}$ が内部酸化物とし て形成されることになる。酸化初期では，この $\mathrm{FeAl}_{2} \mathrm{O}_{4}$ 先 端の酸素分圧は $\mathrm{FeAl}_{2} \mathrm{O}_{4}$ の安定領域にあるため, $\mathrm{A} 1$ と $\mathrm{Fe}$ は酸素 $(\mathrm{O})$ と反応して $\mathrm{FeAl}_{2} \mathrm{O}_{4}$ を形成する． $\mathrm{Fe}-\mathrm{Al}$ 合金中の $\mathrm{Al}$ の应散のための活性化ェネルギーが酸素のそ礼よりる大 きいため(16)(17), Ahmed らの $1173 \mathrm{~K}$ K比較して, 本実験の $1073 \mathrm{~K}$ では， $\mathrm{FeAl}_{2} \mathrm{O}_{4}$ 層の先端に形成されている $\mathrm{Al}$ 欠之 層では，合金内部からの $\mathrm{Al}$ の桩散より酸素の内部への桩 散が有利になると考兵られる。従って， $\mathrm{FeAl}_{2} \mathrm{O}_{4}$ 層の先端か ら少し離れた場所で $\mathrm{Al}_{2} \mathrm{O}_{3}$ を生成・成長し，その結果とし て, $\mathrm{FeAl}_{2} \mathrm{O}_{4}$ 層と $\mathrm{Al}_{2} \mathrm{O}_{3}$ 層の間に内部酸化物の少ない層が形 成されたものと考光られる(Fig. 11(c)，(d)参照)。

$5 \mathrm{Al}$ 合金は内部酸化と外部酸化の臨界組成に近いため, 場 所により内部酸化と外部酸化がそれぞれ観察されている。こ の外部酸化が観察された部分は7A1 と類似の機構で説明さ れる。乙かし, 内部酸化の挙動は時間的に複雑な变化を示し た。すなわら，短時間では $\mathrm{FeAl}_{2} \mathrm{O}_{4}$ と $\mathrm{Al}_{2} \mathrm{O}_{3}$ の複層の内部 酸化物を形成し，3A1のそれと同様火考完られる。しかし， 時間の経過とともに，相対的に $\mathrm{Al}_{2} \mathrm{O}_{3}$ 層が成長し，さらに はロッド状からネットワーク状に变化した。これは, 内部酸

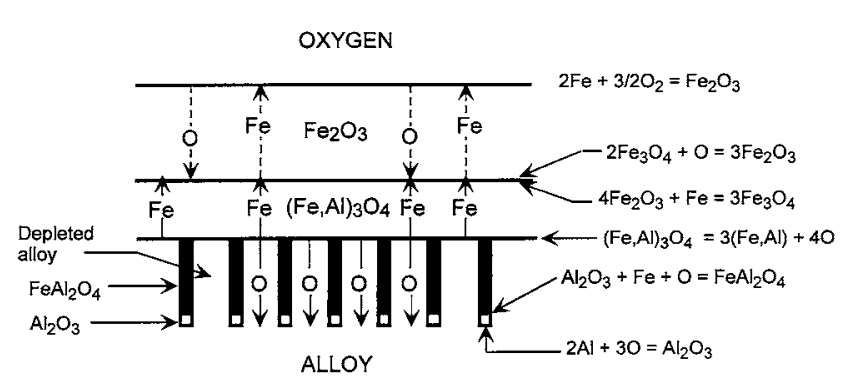

Fig. 10 A model proposed by Ahmed et al. ${ }^{(2)}$ for growth of the surface scale and internal oxidation for $\mathrm{Fe}-1.5,3$ at $\% \mathrm{Al}$ alloys at $1173 \mathrm{~K}$.

Table 1 Solubility and diffusion coefficients of oxygen and aluminum in $\mathrm{Fe}-7,5,3 \mathrm{Al}$ alloys ${ }^{(16)(17)}$, and molar volume of metal (Fe) and oxide $\left(\mathrm{AlO}_{1.5}\right)$ used for calculations.

\begin{tabular}{|c|c|c|c|c|c|c|}
\hline & $\begin{array}{c}N_{\delta}^{(\mathrm{S})(16)} \\
\text { (mole fraction) }\end{array}$ & $\begin{array}{c}N_{\mathrm{Al}}^{(\mathrm{O})} \\
\text { (mole fraction) }\end{array}$ & $\begin{array}{c}D_{\delta}^{(16)} \\
\left(\mathrm{m}^{2} \cdot \mathrm{s}^{-1}\right)\end{array}$ & $\begin{array}{c}D_{A 1}^{17)} \\
\left(\mathrm{m}^{2} \cdot \mathrm{s}^{-1}\right)\end{array}$ & $\begin{array}{c}V_{\text {metal }} \\
\left(\mathrm{m}^{3} \cdot \mathrm{mol}^{-1}\right)\end{array}$ & 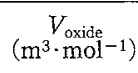 \\
\hline $\mathrm{Fe}-7$ mass $\% \mathrm{Al}$ & $3.28 \times 10^{-6}$ & 0.135 & $1.20 \times 10^{-11}$ & $3.69 \times 10^{-16}$ & \multirow{2}{*}{$7.095 \times 10^{-6}$} & \multirow{2}{*}{$13.9 \times 10^{-6}$} \\
\hline $\mathrm{Fe}-3$ mass $\% \mathrm{Al}$ & " & 0.0602 & " & $3.03 \times 10^{-16}$ & & \\
\hline
\end{tabular}


Fe Oxides (a)

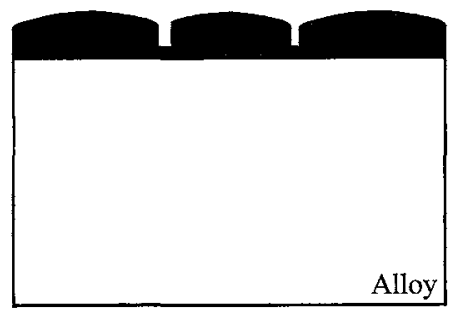

(b)

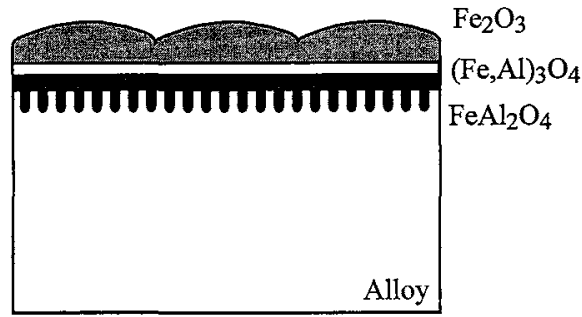

(c)

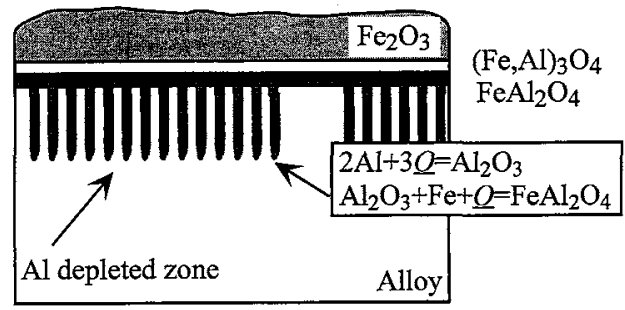

(d)

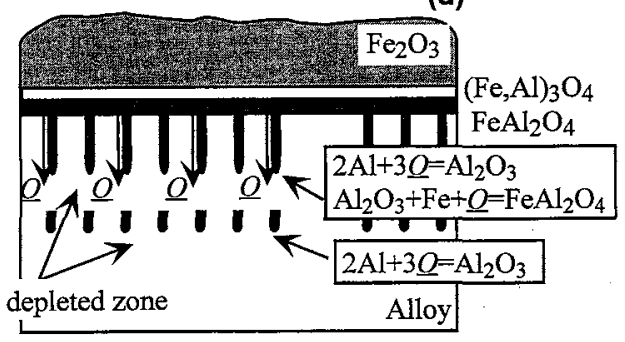

Fig. 11 Models for growth of the scale and internal oxidation of $\mathrm{Fe}-3 \mathrm{Al}$ alloy as a function of time.

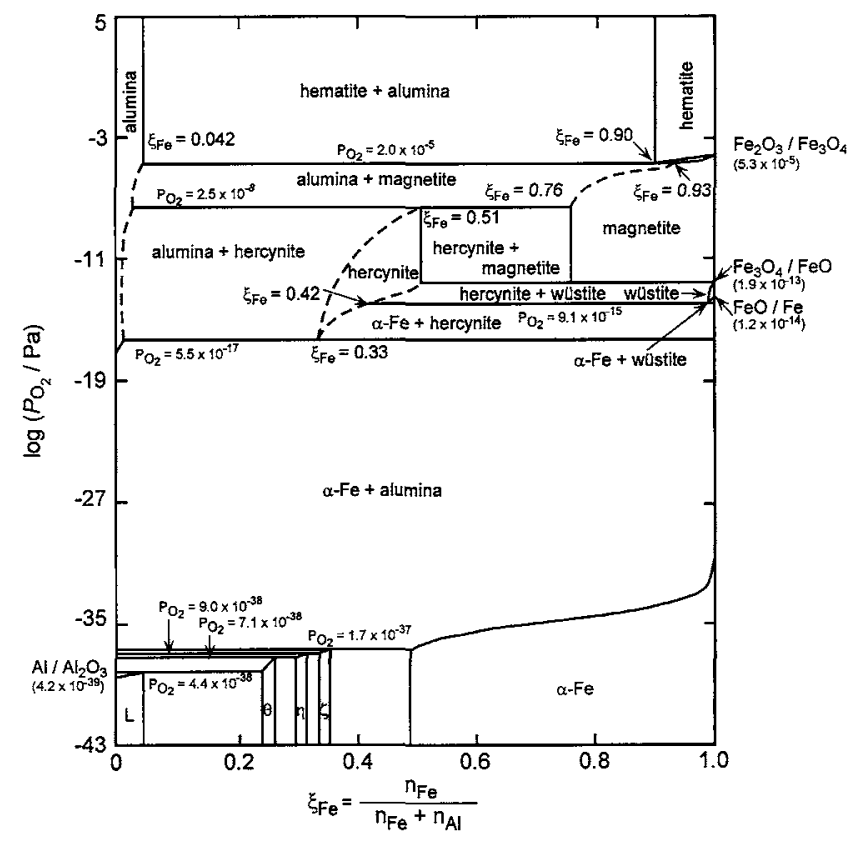

Fig. 12 A phase diagram for an Fe-Al-O system at 1073 $\mathrm{K}^{(19)}$.

化層が厚くなるにつれて酸素の供給速度に対して母材からの $\mathrm{Al}$ の供給が相対的に増大するため，合金内部で内部酸化か ら外部酸化への遷移が生じていると考えることができる。

内部酸化物はネットワーク状の他に, 繊維状, 塊状, $ッ ッ$ ド状，フイルム状，などの多くの形態をとることが明らかと なった。これら内部酸化物の成長機構は定性的に次のように 考察される。

合金内部の溶質元素の拡散が非常に荤いとき，界面は不安
定となり，酸化物はスパイク状に合金内部へ刺さった形態を とることが報告されている(20)-(23)。この事から， Fe-低 $\mathrm{Al}$ 合金の $\mathrm{Al}$ の拡散は酸素 $O$ の拡散に比較して非常に遅い(17) と考光られることから，スケール合金界面は不安定になり， さらに, 内部酸化物と母材の界面が酸素の高速抎散路となり らることから，繊維状の酸化物が合金表面に垂直に成長した ものと思われる。

一方，内部酸化物粒子の寸法は核生成速度と粒子の成長速 度との競合により決定(21)(24)(25)されるので, 内部酸化層の 成長速度が大きい注ど粒子は小さくなる，内部酸化層の成長 が放物線則に従い，層内の各元素の濃度分布は直線的である と仮定すれば，成長速度は次式で与兄られる。

$$
v=\frac{\mathrm{d} X}{\mathrm{~d} t}=\frac{N_{\mathrm{O}}^{(\mathrm{S})} D_{\mathrm{O}}}{v N_{\mathrm{Al}}^{(\mathrm{O})}} \frac{1}{X}
$$

本実験で使用した合金の $\mathrm{Al}$ 濃度とTable 1 の值を式 (2)に 代入すると，内部酸化層の成長速度はそれぞれ

$$
\begin{aligned}
& v^{5 \text { mass } \% \mathrm{Al}}=2.7 \times 10^{-12} \frac{1}{X} \\
& v^{3 \mathrm{mass} \% \mathrm{Al}}=4.4 \times 10^{-12} \frac{1}{X}
\end{aligned}
$$

となり，3Al では酸化物はより早く合金内部へ成長するのに 対して，5Al では横方向へ成長しやすい傾向にあり，フィル ム状の $\mathrm{Al}_{2} \mathrm{O}_{3}$ の形成が可能であったことが理解される.

\section{V. 結論}

$\mathrm{Fe}-3,5,7$ mass \% Al 合金の純酸素, $1073 \mathrm{~K}$ K打忷る酸化 挙動を調査し，以下の結論が得られた。

(1) 3 mass \% Al では内部酸化が観察され， 7 mass \% $\mathrm{Al}$ で 
は均一な外部スケールが生成した。

（2） 3 mass\% $\%$ に和いては，内部酸化組織は試料表面に 垂直であるのに対して， 5 mass\% $\%$ l では，ネットワーク状 のコロニーとその内部にロッド状の内部酸化物が分散した形 態をとった。

（3）内部酸化から外部酸化への遷移濃度は本実験条件下で は， 5 mass\% $\%$ l であり，遷移領域では内部酸化物は部分的 なフィルム状の形態をとる.

\section{文献}

(1) V. Kolarik, H. Fietzek, W. Engel, B. Eltester and H. J. Grabke: Mat. Sci. For., 251-254(1997), 251-258.

(2) H. A. Ahmed and W. W. Smeltzer: J. Electrochem. Soc., $133(1986), 212-216$

(3) F. H. Stott and G. C. Wood: Corros. Sci., 17 (1977), 647-670.

(4) Y. Shida, F. H. Stott, B. D. Bastow, D. P. Whittle and G. C. Wood: Oxid. Met., 18(1982), 93-113.

(5) H. M. Hindam and W. W. Smeltzer: J. Electrochem. Soc., $127(1980), 1622-1630$.

(6) F. A. Elrefaie and W. W. Smeltzer: Oxid. Met., 17(1982), 407-413.

(7) F. H. Stott, Y. Shida, D. P. Whittle, G. C. Wood and B. D. Bastow: Oxid. Met., 18(1982), 127-146.
(8) J. S. Wolf and E. B. Evans: Corrosion, 18(1962), 129t-136t.

(9) P. Tomaszewicz and G. R. Wallwork: Oxid. Met., 19(1983), 165-185.

(10) P. J. Smith, R. M. Beauprie, W. W. Smeltzer, D. V. Stevanovic and D. A. Thompson: Oxid. Met., 28(1987), 259276.

(11) F. Saegusa and L. Lee: Corrosion, 22(1966), 168-177.

(12) William E. Boggs: J. Electrochem. Soc., 118(1971), 906-913.

(13) S. Hayashi and T. Narita: Collected Abstracts of the 1998 Autumn Meeting of the Japan Inst. Metals, p. 99.

(14) S. Hayashi and T. Narita: Collected Abstracts of the 1999 Spring Meeting of the Japan Inst. Metals, p. 128.

(15) C. Wagner: Z. Elektrochem., 63(1959), 772-782.

(16) J. Tanaka, S. Yamamoto, S. Kikuchi and M. Adachi: Oxid. Met., 25(1986), 93-105.

(17) K. Nishida, T. Yamamoto and T. Nagata: J. Japan Inst. Metals, 34(1970), 591-596.

(18) R. A. Rapp: Acta Metall., 9 (1961), 730-741.

(19) F. A. Elrefaie and W. W. Smeltzer: Met. Trans. B, 14(1983), 85-93.

(20) G. Böhmm and M. Kahlweit: Acta Metall., 12(1964), 641-648.

(21) C. Wagner: J. Electrochem. Soc., 103(1956), 627-633.

(22) C. Wagner: J. Electrochem. Soc., 103 (1956), 571-580.

(23) P. Kofstad: HIGH TEMPERATURE CORROSION, Elsevier Applied Science, (1988), pp. 352.

(24) K. Nishida and T. Narita: collaboration Kinzokuno Kouonsanka Nyuumon, Maruzen, (1988), pp. 99.

(25) D. P. Whittle, Y. Shida, G. C. Wood, F. H. Stott and B. D. Bastow: Philos. Mag. A, 46(1982), 931-949. 